\title{
Dugaan Siswa Terhadap Masalah Open Classical Analogy Tipe A - C
}

\author{
Malik Abdul Azis ${ }^{1 *}$, Enita $^{2}$, Lieska Maulita Shamimi ${ }^{3}$, Shofan Fiangga ${ }^{4}$ \\ 1,2,3,4 Universitas Negeri Surabaya, Surabaya, Jawa Timur 60231, Indonesia \\ Pengiriman: 15/Mei/2020; Diterima: 23/September/2020; Publikasi: 30/September/2020 \\ DOI: https://doi.org/10.31629/jg.v5i2.2265
}

\begin{abstract}
Abstrak
Kemampuan pengajuan dugaan merupakan kemampuan siswa dalam membuat dugaan hasil yang akan didapat dari suatu kegiatan atau masalah matematis. Salah satu masalah matematis yang memerlukan konjektur adalah Open Classical Analogy (OCA). Pada masalah OCA siswa dituntut untuk berpikir kreatif dalam menduga sifat dari suatu hal tertentu yang belum diketahui sebelumnya menggunakan analogi dengan hal yang telah mereka ketahui. Penelitian ini merupakan penelitian deskriptif kualitatif yang bertujuan untuk mendeskripsikan proses pengajuan dugaan yang diberikan oleh siswa berdasarkan tingkat kemampuan penalaran siswa. Subyek penelitian ini adalah tiga siswa SMP kelas 9 di Surabaya yang dipilih dari 30 siswa yang memiliki tingkat kemampuan penalaran berbedabeda. Hasil dari penelitian ini adalah kemampuan penalaran siswa berpengaruh pada bagaimana siswa tersebut mengajukan suatu dugaan dari property pengetahuan baru yang memiliki kesamaan dengan pengetahuan yang telah dipelajari sebelumnya.
\end{abstract}

Kata kunci: kemampuan pengajuan dugaan; masalah OCA

\section{Abstract}

The ability to submit allegations is the ability of students to make guesses about the results that will be obtained from an activity or mathematical problem. One of the mathematical problems that require conjecture is Open Classical Analogy (OCA). In OCA problems, students are required to think creatively in guessing the nature of particular things that have not been known before using analogy with things they already know. This research is a qualitative descriptive study which aims to describe the process of submitting the allegations given by students based on the level of students' reasoning abilities. The subjects of this study were three students of grade 9 in Surabaya who were selected from 30 students who had different levels of reasoning ability. The result of this study is that students' reasoning abilities affect how these students propose an assumption of new knowledge properties that have similarities with previously learned knowledge.

Keywords: ability to submit allegations; OCA problems 


\section{JURNAL GANTANG. September 2020; V(2): 163 - 170 \\ p-ISSN. 2503-0671 \\ e-ISSN. 2548-5547}

\section{Pendahuluan}

Analogi merupakan salah satu bentuk dari penalaran induktif. Analogi merupakan kemampuan seseorang dalam melihat hubungan keterikatan antara objek maupun ide yang kemudian digunakan untuk memeroleh suatu hal yang lain (Ahman, 2013). Analogi menurut Soekadijo tidak lain adalah membandingkan dua hal yang memiliki kesamaan (Soekadijo et al., n.d.). Menurut Akhadiah analogi merupakan proses penalaran yang bertujuan untuk membuat kesimpulan yang didasari dengan kesamaan aspek dua hal tertentu (Akhadiah, 2015). Sehingga dapat disimpulkan analogi adalah proses kognitif dalam diri seseorang dengan cara mentransfer informasi atau makna dari suatu topik tertentu (sumber) ke topik yang lain (target).

Penalaran analogi menurut Lee dan Sriraman merupakan suatu cara yang dilakukan seseorang untuk memperoleh pengetahuan baru menggunakan kemiripan atau kesamaan dengan pengetahuan yang telah dimiliki (Sriraman, 2004). Lee dan Sriraman menambahkan tiga aspek penting yang ada dalam penalaran analogi, yaitu aspek sumber, kesamaan, dan aspek target (Lee \& Sriraman, 2010). Soal atau masalah mengenai penalaran analogi biasanya terdiri dari dua soal yaitu masalah sumber dan masalah target (English, 2004). Masalah sumber adalah masalah yang telah dipelajari sebelumnya dan berkaitan dengan materi yang akan dipelajari, sedangkan masalah target adalah masalah dipecahkan dengan mencari kesamaan atau kemiripan dengan masalah sumber (Lee \& Sriraman, 2010). Stemberg mengungkapakan bahwa dalam berpikir analogi haru melalui beberpa proses sebagaimana yang disajikan dalam sebuah diagram pada Gambar 1 (Sriraman, 2004).

Dalam pendidikan matematika pembentukan pengetahuan dan pengembangan konsep dalam diri seseorang merupakan peristiwa yang berulang-ulang (Boero et al., 2002). Pada peristiwa tersebut penalaran analogi mempunyai peran penting dalam pembentukan pengetahuan dan pengembangan konsep (Sriraman, 2004). 
siswa dapat terlibat secara aktif untuk pembentukan pengetahuannya sendiri berdasarkan pada kemampuan dirinya sendiri.

Ketika siswa terlibat secara aktif dalam pembentukan dan pengembangan pengetahuan mereka sendiri, maka pengetahuan yang mereka dapat akan bertahan lebih lama daripada siswa yang hanya mendengarkan penjelasan materi yang diberikan guru (Lakatos, 2015). Karena itu masalah yang mengharuskan siswa mencari secara mandiri istilah "B", "C", dan "D" dari analogi klasik, disebut masalah Open Classical Analogy (OCA). Masalah OCA pada umumnya mengaharuskan siswa untuk mencari sendiri istilah "B", "C", dan "D", akan tetapi gurujuga dapat merancang tiga jenis masalah OCA bergantung pada kemampuan yang dimiliki oleh siswa dan istilah mana yang diberikan oleh guru yaitu tipe A-C, tipe A-B, dan tipe A only.

Jika dirasa kemampuan siswanya kurang dalam hal matematika, guru dapat memulai dengan memberikan istilah "A" dan "C" (tipe AC) pada masalah OCA, kemudian jika dirasa kemampuan siswa cukup dalam matematika guru dapat memberikan siswa istilah "A" dan "B" (Tipe A-B) pada masalah OCA, dan jika dirasa kemampuan siswanya tinggi dalam matematika guru dapat memberikan siswa istilah "A" saja (Tipe A only) pada masalah OCA. Contoh dari tiga jenis masalah OCA tersebut seperti disajikan pada tabel berikut.

Tabel 1.

Contoh dari istilah tipe analogi klasik

\begin{tabular}{|c|c|}
\hline $\begin{array}{l}\text { Tipe Analogi } \\
\text { Klasik }\end{array}$ & Contoh \\
\hline Tipe A-C & $\begin{array}{l}\text { Andaikan persegi mirip dengan } \\
\text { segitiga. Dugalah properti } \\
\text { persegi yang mirip dengan } \\
\text { property segitiga yang sudah } \\
\text { Anda ketahui. Jelaskan } \\
\text { jawabanmu. }\end{array}$ \\
\hline Tipe A-B & $\begin{array}{l}\text { Jumlah sudut dalam suatu } \\
\text { segitiga adalah } 180^{\circ} \text {. Dugalah } \\
\text { properti yang serupa dari setiap } \\
\text { bangun datar yang mirip dengan } \\
\text { segitiga. Jelaskan jawabanmu. }\end{array}$ \\
\hline Tipe A Only & $\begin{array}{l}\text { Pilih suatu bangun datar yang } \\
\text { mirip dengan segitiga dan } \\
\text { buatlah dugaan tentang properti }\end{array}$ \\
\hline
\end{tabular}

\begin{tabular}{|c|c|}
\hline $\begin{array}{c}\text { Tipe Analogi } \\
\text { Klasik }\end{array}$ & Contoh \\
\hline & $\begin{array}{l}\text { bangun datar tersebut yang mirip } \\
\text { dengan properti segitiga. } \\
\text { Jelaskan jawabanmu. }\end{array}$ \\
\hline
\end{tabular}

Secara umum, guru dapat memodifikasi banyak masalah dalam matematika sekolah menjadi masalah OCA. Masalah OCA dapat meningkatkan kemampuan matematis yang dimiiki siswa, sehingga penting bagi guru untuk memberikan masalah OCA bagi siswa agar dapat meningkatkan kemampuan matematis siswa.

Salah satu keterampilan penalaran adalah kemampuan mengajukan dugaan. Dugaan merupakan pernyataan yang diyakini benar akan tetapi belum dibuktikan kebenarannya (Supratman et al., 2016). Pengajuan dugaan sangat penting dalam pendidikan karena bermanfaat untuk mengembangkan wawasan baru dan kajian lebih lanjut. Dalam masalah OCA, pengajuan dugaan digunakan dalam menduga property atau sifat (D) materi atau objek target (C) yang analog atau mirip dengan hubungan antara "A" dan "B".

Penelitian mengenai Masalah OCA salah satunya telah dilakukan oleh Lee \& Sriraman tahun 2010 di Korea. Pada penelitian ini Lee \& Sriraman melakukan penelitian pada siswa SD dalam materi bangun datar segiempat yang dibandingkan dengan bangun datar segitiga. Tujuan dari penelitian tersebut untuk mendiskripsikan proses pengajuan dugaan yang dilakukan siswa dalam masalah OCA Tipe A only. Hasil yang diperoleh menunjukan bahwa terdapat beberapa siswa yang mampu menduga property dari segiempat yang analog dengan segitiga, salah satunya adalah jumlah sudut segiempat $360^{\circ}$.

Penelitian tersebut mengilhami peneliti untuk melakukan penelitian yang berkaitan dengan kemampuan konjektur siswa dalam masalah OCA untuk menduga sifat dalam materi SPLTV. Penelitian dilakukan pada 3 siswa kelas 9 yang memiliki tingkat kemampuan pengajuan dugaan yang berbeda-beda. Materi yang dipilih peneliti adalah Metode Penyelesaian pada 
JURNAL GANTANG. September 2020; V(2): 163 - 170

p-ISSN. 2503-0671

e-ISSN. 2548-5547

SPLTV. Materi ini dipilih karena SPLTV memiliki hubungan atau kemiripan yang erat dengan Metode Penyelesaian SPLDV yang telah siswa pelajari sebelumnya pada kelas 8 semester 2 , sehingga siswa dapat menggunakan penalaran analogi mereka dalam mengerjakannya.

\section{Metode Penelitian}

Penelitian ini memiliki tujuan untuk mendeskripsikan proses pengajuan dugaan yang diberikan oleh siswa berdasarkan tingkat kemapuan penalaran siswa. Untuk memperoleh deskripsi proses pengajuan dugaan siswa, hal pertama yang dilakukan peneliti adalah memberikan LKPD masalah OCA tipe A-C kepada siswa. Kemudian untuk mendapatkan data yang lebih mendalam mengenai dugaan yang dikemukakan siswa, dilakukan wawancara kepada siswa. Karena hal tersebut, jenis penelitian ini adalah deskriptif kualitatif. Subyek penelitian ini adalah tiga siswa SMP kelas 9 di Surabaya yang dipilih berdasarkan tingkat kemampuan penalaran.Ketiga siswa tersebut dipilih dari 30 siswa yang memiliki tingkat kemampuan penalaran berbeda-beda.

Untuk mempermudah dalam mendeskripsikan data, maka kemapuan penalaran siswa akan dibedakam menjadi 3 tingkatan sebagai berikut.

Tabel 2.

Pembagian tingkatan kemampuan penalaran siswa

\begin{tabular}{cl}
$\begin{array}{c}\text { Tingkat } \\
\text { Kemampuan } \\
\text { Penalaran }\end{array}$ & \multicolumn{1}{c}{ Ciri-ciri Tingkat Kemampuan } \\
& Penalaran \\
\hline & $\begin{array}{l}\text { Dapat menyajikan pernyataan } \\
\text { matematis dengan lengkap } \\
\text { - }\end{array}$ \\
Dapat melakukan manipulasi \\
matematika dan mendapatkan \\
& hasil yang tepat. \\
& - Dapat menarik kesimpulan \\
& dengan benar disertai dengan \\
& bukti dan alasan yang tepat \\
& - Menyajikan pernyataan \\
& matematis kurang lengkap \\
& - Melakukan manipulasi \\
& matematika dengan benar \\
Tingkat 2 & namun kurang lengkap \\
& - Menarik kesimpulan dengan \\
& benar namun bukti dan alasan \\
& kurang lengkap \\
\hline &
\end{tabular}

\begin{tabular}{cl}
\hline $\begin{array}{c}\text { Tingkat } \\
\text { Kemampuan } \\
\text { Penalaran }\end{array}$ & \multicolumn{1}{c}{ Ciri-ciri Tingkat Kemampuan } \\
Penalaran
\end{tabular}

(diadopsi dari tabel penskoran (Nailil, 2011)

Selanjutnya, data dianalisis untuk mendapatkan kesimpulan dari hasil penelitian. Data dianalisis secara kualitatif, dilakukan dengan bekerja dengan data, mengatur data, mereduksinya menjadi unit yang dapat dikelola, mensintesisnya, menemukan pola, menemukan apa yang penting dan apa yang dipelajari, dan memutuskan apa yang bisa diceritakan kepada orang lain (Milles \& Huberman, 2014). Mengacu pada hal tersebut ada enam tahapan analisis data kualitatif yang dilakukan, yaitu: (1) meninjau semua data; (2) mereduksi data; (3) menyusun dalam unit; (4) mengelompokkan data; (5) pengkodean; dan (6) memeriksa data.

\section{Hasil dan Pembahasan}

Kemampuan Pengajuan Dugaan Siswa dengan Kemampuan Penalaran Tingkat 3 (P3)

Gambar 2 di bawah ini menunjukkan jawaban 1 dari subyek P3. Berdasarkan informasi yang didapat dari Gambar 1, P3 menduga Metode Penyelesaian SPLTV yaitu eliminasi.

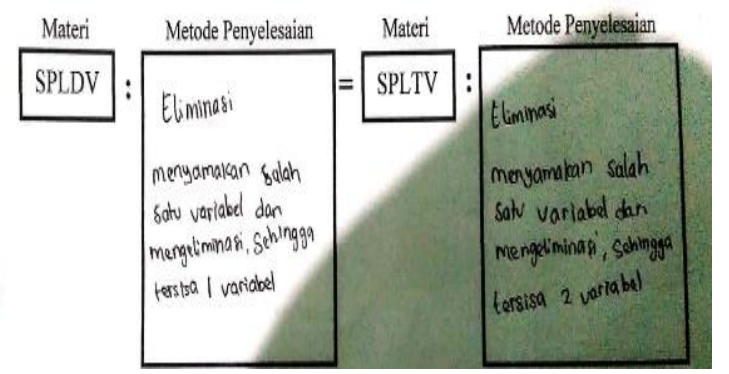

Gambar 2. Jawaban 1 Subyek P3 


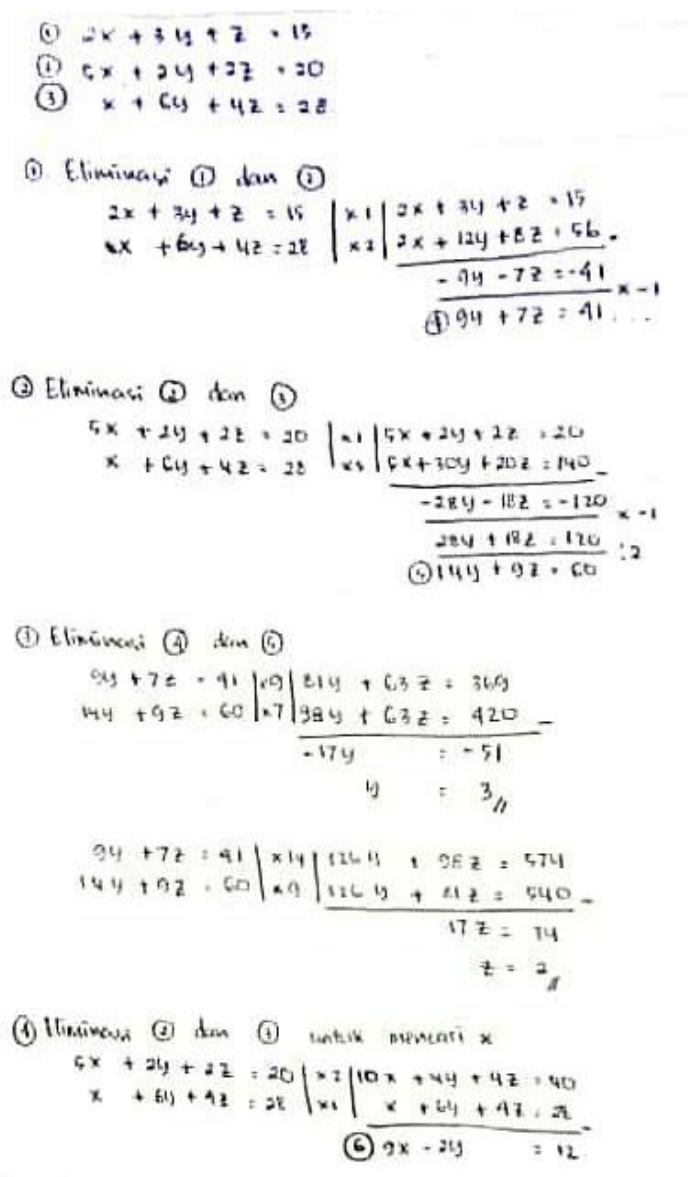

Gambar 3. Jawaban 2.1 subyek P3

P3 menduga bahwa eliminasi yang dilakukan pada SPLTV sama dengan SPLDV yaitu menyamakan salah satu variabel dan mengeliminasinya hanya saja pada SPLTV sisa variabel setelah di eliminasi adalah 2 variabel.

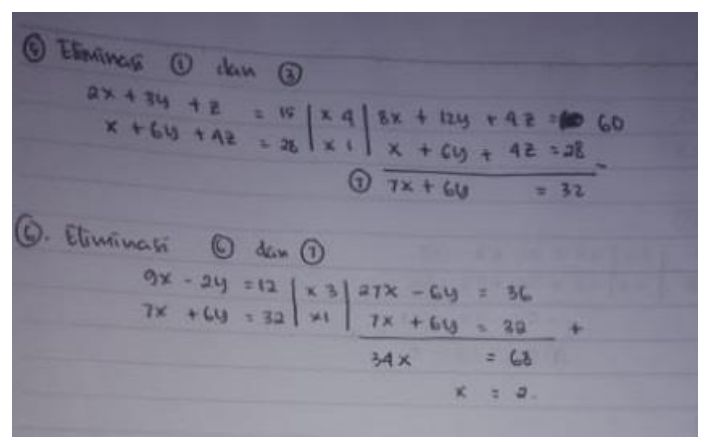

Gambar 4. Jawaban 2.2 subyek P3

Transkip Wawancara Subyek P3

P301P: Bagimana kamu menemukan penyelesaian dari soal soal SPLTV tersebut?

P302S: Ya, yang pertama saya melakukan eliminasi pada pers pertama dengan pers ketiga dan pers kedua dengan pers ketiga

P303P : Oke. Terus bagaimana proses eliminasi pada itu tadi?

P304S : Saya samakan x nya, kemudian saya kurangkan

P305P : Kenapa kamu melakukan itu?

P306S : Ya untuk mendapatkan dua persamaan linier dua variabel yaitu variabel y dan $\mathrm{Z}$

P307P: Kemudian apa yang kamu lakukan setelah mendapatkannya?

P308S : Lalu saya melakukan eliminasi lagi seperti pada SPLDV itu, untuk nemuin nilai dari y sama $\mathrm{z}$ nya

P309P : Oke setelah ketemu nilai y sama z nya terus kamu ngapain?

P310S : Ya setelah itu saya nyari nilai $x$ nya mas kan penyelesaian SPLTV butuh $\mathrm{x}$, y sama $\mathrm{z}$.

P311P : Bagaimana kamu nentuin nilai $\mathrm{x}$ ?

P312S: Ya sama seperti tadi, hanya proses eliminasi pertama yang disamain bukan $\mathrm{x}$ nya tapi nilai $\mathrm{z}$ nya. Sehingga ketemu lagi dua persamaan linier dua variabel tapi sekarang variabelnya $\mathrm{x}$ sama y, kemudian di elimasi lagi untuk memeproleh $\mathrm{x}$ nya

Setelah melakukan wawancara didapat bahwa P3 menduga seperti itu karena dia mengetahui bahwa pada SPLDV terdapat 2 variabel dan jika di eliminasi salah satu hanya tinggal satu variabel yang tersisa, sedangkan pada SPLTV yang memiliki 3 variabel jika salah satunya di eliminasi akan menyisakan 2 variabel.

Pada penerapan hasil yang didapat, P3 mampu mengintepretasikan dugaannya ke soal SPLTV yang diberikan dengan tepat dan menemukan jawaban yang tepat. P3 melakukan eliminasi pada (1) dengan (3) kemudian (2) dengan (3) untuk mendapatkan dua persamaan yang terdiri dari 2 variabel y dan z. Kemudian dua persamaan tersebut di eliminasi seperti dalam SPLDV dalam menentukan nilai y dan z. Lalu P3 
JURNAL GANTANG. September 2020; V(2): 163 - 170

p-ISSN. 2503-0671

e-ISSN. 2548-5547

mengulangi prosesnya dari awal yaitu melakukan eliminasi pada (1) dengan (3) kemudian (2) dengan (3) untuk mendapatkan dua persamaan yang terdiri dari 2 variabel $\mathrm{x}$ dan $\mathrm{y}$. Terakhir, P3 melakukan eliminasi kembali untuk menemukan nilai dari $\mathrm{x}$.

\section{Kemampuan Pengajuan Dugaan Siswa dengan Kemampuan Penalaran Tingkat 2 (P2)}

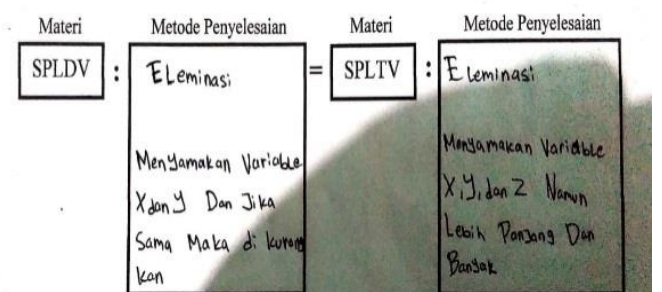

Gambar 5. Jawaban 1 subyek P2

P2 menduga Metode Penyelesaian SPLTV yaitu eliminasi. P2 menduga bahwa eliminasi yang dilakukan pada SPLTV hampir sama dengan SPLDV yaitu menyamakan variabel hanya saja pada SPLTV ada tambahan variabel z dan prosesnya lebih panjang dan banyak dari pada SPLDV.

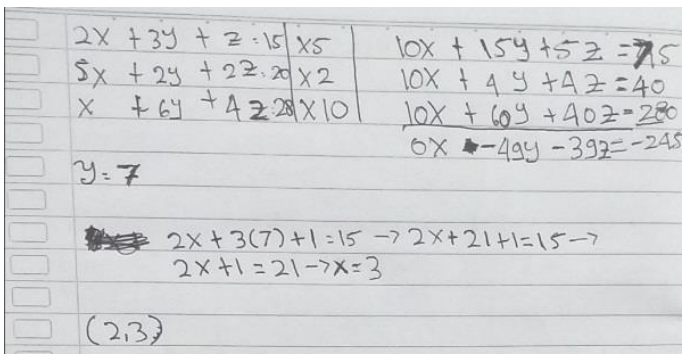

Gambar 6. Jawaban 2 subyek P2

Transkip Wawancara Subyek P2

P201P : Bagaimana kamu menemukan penyelesaian dari soal soal SPLTV tersebut?

P202S : Awalnya saya melakukan eliminasi mas pada semua persamaan

P203P : Oke. Kenapa kamu lakukan itu ?

P204S : Kan sama seperti SPLDV mas, kedua persamaan pada SPLDV di eliminasi jadi kalo SPLTV ya berarti ketiga persamaannya kan

P205P : Oke, eliminasinya gimana? Terus apa yang kamu dapat?
P206S : Saya samain x nya semua kemudian saya kurangkan semuanya, ya yang saya dapat itu mas persamaan linier dua variabel y dan $\mathrm{z}$

P207P : Lalu y $=7$ itu apa?

P208S: Hehe... itu saya ngasal aja mas, bingung mau nerusin gimana lagi

P209P : Terus yang bawah itu, kok kamu bisa nemuin nilainya $\mathrm{x}$ ?

P210S : Hehehe... itu saya ngasal juga mas, saya ngambil persamaan pertama kemudian saya subtitusikan y nya itu 7 dan $\mathrm{z}$ nya itu 1 jadi saya operasikan ketemu deh nilai $x$ nya

P211P : z nya 1 itu dari mana ? dan $(2,3)$ itu apa?

P212S : Kalo z nya 1 itu sama mas, saya ngasal aja. Kalo $(2,3)$ itu bukan apa-apa kok mas hanya coretan saja

Setelah melakukan wawancara didapat bahwa P2 menduga seperti itu karena dia mengetahui bahwa pada SPLDV terdapat 2 variabel dan SPLTV terdapat 3 variabel sehingga P3 menduga pasti SPLTV memiliki yang proses yang lebih panjang dan banyak dibandingkan SPLDV.

Pada penerapan hasil yang didapat, P2 kurang mampu mengintepretasikan dugaannya ke soal SPLTV yang diberikan dengan tepat sehingga P2 tidak dapat menemukan jawaban yang tepat. P2 melakukan eliminasi pada (1), (2) dan (3) sekaligus dengan menyamakan variabel x sehingga didapat satu persamaan linier dua variabel. Kemudian karena hanya tinggal satu persamaan, P2 merasa bingung dalam meneruskan pekerjaanya. P2 lalu mengklaim bahwa $\quad \mathrm{y}=7 \quad$ sehingga $\quad \mathrm{P} 2$ meneruskan pekerjaannya sampai didapat nilai $\mathrm{x}=3$, akan tetapi P2 masih kesulitan dalam mencari nilai z, sehingga P2 menghentikan pekerjaannya.

\section{Kemampuan Pengajuan Dugaan Siswa dengan Kemampuan Penalaran Tingkat 1 (P1)}

Gambar 7 menunjukkan jawaban 1 dari subyek P1. Berdasarkan informasi yang didapat dari Gambar 7, P1 menduga Metode Penyelesaian 
SPLTV sama dengan metode SPLDV yaitu subtitusi, eliminasi dan gabungan.

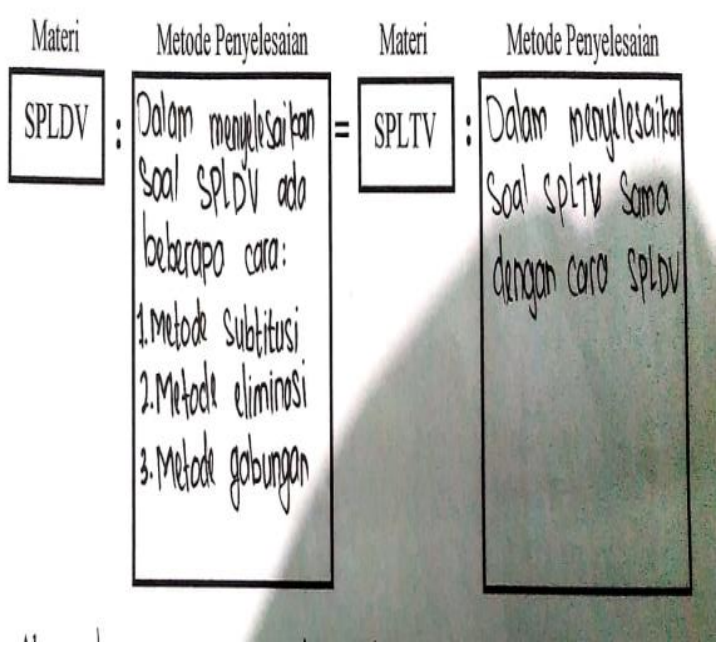

Gambar 7. Jawaban 1 subyek P1

Setelah melakukan wawancara didapat bahwa P1 menduga seperti itu karena dia hanya memahami bahwa SPLDV dan SPLTV hanya bilangan-bilangan dan variabel yang dioperasikan dengan operasi $(=),(+)$, dan atau (-) sehingga SPLDV dan SPLTV memiliki metode penyelesaian yang sama.

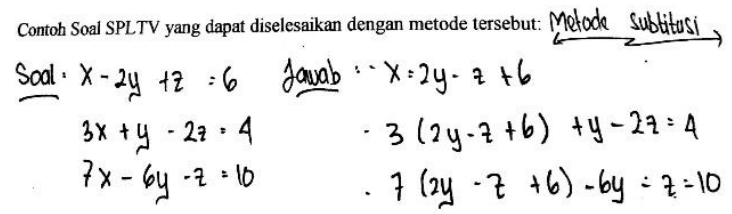

Gambar 8. Jawaban 2 Subyek P1

Transkip Wawancara Subyek P1

P101P : Bagimana kamu dapat menemukan penyelesaian dari soal soal SPLTV tersebut?

P102S: Awalnya saya ubah mas persamaan pertama ke bentuk $\mathrm{x}$ kemudian saya subtitusikan ke persamaan kedua dan ketiga

P103P : Oke, kemudian kamu kenapa berhenti?

P104S : Saya bingung mas melanjutknnya bagaimana

P105P : Memang apa yang membuat kamu bingung?
P106S : Ya itu mas, nanti kalo saya lanjutkan ketemu dua variabel y sama $\mathrm{z}$ di kedua persamaannya, lah itu yang saya bingung mas

Pada penerapan hasil yang didapat, P1 tidak mampu mengintepretasikan dugaannya ke soal SPLTV yang diberikan dengan tepat sehingga P1 tidak dapat menemukan jawaban yang benar.

Setelah dilakukan wawancara P1 mengubah persamaan pertama kedalam bentuk $\mathrm{x}$. Kemudian P1 mensubtitusikan hasilnya ke persamaan kedua dan ketiga. P1 lalu merasa bingung untuk melanjutkan pekerjaannya karena P1 menemukan dua persamaan yang meiliki 2 variabel y dan 2 variabel $\mathrm{z}$, sehingga $\mathrm{P} 1$ menghentikan pekerjaannya sampai pensubtitusian.

\section{Kesimpulan}

Penelitian ini mendeskripsikan kemampuan pengajuan dugaan siswa dalam masalah Open Classical Anlogy. Temuan dalam penelitian ini adalah P3 mampu menduga sifat dari materi yang belum dipelajari dengan benar menggunakan analogi atau mencari kesamaan dengan sifat dari materi yang telah dipelajari sebelumnya, sedangkan P2 dan P1 tidak/kurang bisa menduga suatu materi yang baru menggunakan analogi dengan materi yang telah dipelajari. Penelitian ini menunjukkan bahwa siswa yang memiliki tingkat penalaran yang lebih tinggi cenderung dapat menduga property dari materi baru yang memiliki kesamaan dengan materi yang telah mereka pelajari sebelumnya.

\section{Referensi}

Ahman M, S. (2013). Conjecturing via analogical reasoning to explore creative thinking. In Proceedings of the 2013 International Conf. on Math. Edu. on Creativity \& Giftedness (pp.305-316). Korea : The Korean Society of Mathematical Education.

Akhadiah, S. (2015). Filsafat Ilmu Lanjutan. Jakarta: Kencana.

Boero, P., Dreyfus, T., Gravemeijer, K., Gray, E., Hershkowitz, R., \& Schwarz, B. (2002). 
JURNAL GANTANG. September 2020; V(2): 163 - 170

p-ISSN. 2503-0671

e-ISSN. 2548-5547

Abstraction: Theories about the emergence of knowledge structures. Proceedings of the 26th Annual Conference of the International Group for the Psychology of Mathematics Education. I, (pp 113-138). Norwich :PME

Dunbar, K. (2001). The analogical paradox: Why analogy is so easy in naturalistic settings yet so difficult in the psychological laboratory. In The analogical mind: Perspectives (pp313-334). Massachusetts: The MIT Press.

English, L. (2004). Mathematical and analogical reasoning of young learners. New Jersey: Lawrence Erlbaum \& Associates

Lakatos, I. (2015). Proofs and refutations: The logic of mathematical discovery. Melbourne: Cambride University Press

Lee, K.-H., \& Sriraman, B. (2010). Conjecturing via reconceived classical analogy. Educ Stud Math, 76, 123-140 https://doi.org/10.1007/s10649-010-9274-1

Milles, M., \& Huberman, A. (2014). Analisis Data Kualitatif. Jakarta: UI Press.

Nailil, F. (2011). Pengaruh Kemampuan penalaran dan komunikasi matematika terhadap kemampuan menyelesaikan soal cerita materi pokok himpunan pada peserta didik semester 2 kelas VII MTs. NU Nurul Huda Mangkan Semarang pada tahun pelajaran 2010/2011. (Unpublised Skripsi) IAIN Walisongo, Semarang.

Soekadijo, R., Utama, L. (2001). Simbolik dan Induktif. Jakarta: Gramedia Pustaka Utama

Sriraman, B. (2004). Gifted ninth graders' notions of proof: Investigating parallels in approaches of mathematically gifted students and professional mathematicians. Journal for the Education of the Gifted, 27(4), pp. 267-292). https://doi.org/10.4219/jeg-2004-317

Supratman, Ryane, S., Rustina, R. (2016). Conjecturing via Analogical reasoning in developing scientific approach in junior high school students. Journal of Physics: Conference Series, 693(1), 1-9. https://doi.org/10.1088/1742-

6596/693/1/012017 